\title{
Evaluation of Mango Trees Production Grown Between Date Palms
}

\author{
Rabie I. Saad , G.A.Said and M.Y.Abdalla ${ }^{1}$
}

\begin{abstract}
The effect of intercropping spacing on yield, fruit quality, and leaf chemical composition of Zebda mango trees grown among Zaghloul date palms at Rasheed region, EL-Behera Governorate, Egypt was studied to estimate a suitable intercropping spacing of mango trees on date palms. In general, Zebda mango trees grown at wide intercropping spacing $(6 \times 6 \mathrm{~m}$.) produced the highest yield / tree, represented in increasing number of panicles / tree, number of flowers / panicle, number of fruits / tree and fruit retention $\%$ as compared with those at other intercropping spacing. In addition, wide intercropping system significantly increased fruit quality, represented in fruit dimensions and weight of fruit and pulp with high content of TSS, non-reducing sugars and total sugars \%. Likewise, it significantly increased leaf chlorophyll (a), (b), carbohydrates and some mineral content as $\mathrm{N}, P$ and $K$. Medium intercropping system $(5 \times 5 \mathrm{~m}$.) produced middle values of the studied parameters followed by closed intercropping system $(4 \times 4 \mathrm{~m}$.) which produced the lowest values in this respect.

On the other words, wide intercropping spacing was most suitable for Zebda mango trees grown among date palms, which came in the first class in yield and fruit quality as compared with other intercropping systems and it was similar in most parameters to those of control (traditional cultivation $5 \times 5 \mathrm{~m}$.) and could be as a recommended system under conditions of this study, consequently growers can stop substitution of date palms with mango trees to maximize their output of the limited cultivated lands in this region.
\end{abstract}

\section{INTRODUCTION}

Mango, ( Mangifera indica L.) is one of the most important fruits in Egypt, it occupied 139433 feddans with total production 416951 tons (according to Annals of Agricultural Economics, A.R.E, 2005). At the last few years, the growers in the main regions of date palm plantation in Egypt (Rasheed and Edko, EL-Behera Governorate), tended to cultivated mango trees among date palms, when mango trees reached to economic production, they uproot all date palms from the orchard to prevent the competition of date palms on light and soil nutrient. They adopted this practice in belief that mango trees produced highest income return as compared with date palms. Premaratne and Silva (1991) noticed that intensified cultivation with a large number of mango trees generates substantial financial returns to the growers. Consequently, Egypt will lose these famous regions with date palms. So, the growers are in urgent business to have a sound program for mango intercropping on date palm trees.

For this reason it is very important to study the yield and fruit quality as well as leaf chemical composition of mango trees grown at three different spaces among date palms in comparison with traditional cultivation (without intercropping) to estimate a suitable tree space. No reports are found in the literature concerning the effect of intercropping spacing of mango trees. However the effect of tree spacing on yield and fruit quality have been studied by Avilan (1986) on mango who reported that accumulated yield would be higher in the high density planting system than in the traditional planting system, but yield thereafter would be similar in both systems. Also, other related studies were recorded by Schneider et al. (1978); Mika and Piatkowski (1986) and Rom (1990) on apple and Chalmers et al. (1981) on peach and Smart (1990) and Chipungahelo et al. (1997) on pineapple, Pastor (1984) on olive reported that average annual yield per tree was the highest at the lowest planting density of Manzanillo olive trees.

\section{MATERIALS AND METHODS}

This study was carried out during two successive seasons (2005 and 2006) on 8 years old mango trees (Zebda cultivar) grown in sandy soil with flow irrigation system at Rasheed region, EL-Behera Governorate, at various spacing among 15 years old date palms (Zaghloul cultivar) as intercropping system. Fifteen grafted mango trees as uniform as possible and subjected to the same horticulture practices were chosen from each of four separated orchards as follows:

a) First orchard: mango trees are planted at $5 \times 5$ meters apart (without intercropping) as traditional cultivation or control (T.C.).

b) Second orchard: mango trees are planted at $6 \times 6$ meters apart among date palms which planted at 12 $\times 12 \mathrm{~m}$. as wide intercropping (W.I.).

c) Third orchard: mango trees are planted at $5 \times 5 \mathrm{~m}$. apart among date palms which planted at $10 \times 10 \mathrm{~m}$. as medium intercropping (M.I.).

\footnotetext{
${ }^{1}$ Horticulture Res. Institute, Agric. Res. Center, Giza, Egypt.

Received Feb. 14, 2007, Accepted March, 30, 2007
} 
d) Fourth orchard: mango trees are planted at $4 \times 4$ meters apart among date palms which planted at $8 \times 8$ $\mathrm{m}$. as closed intercropping (C.I.).

Each orchard was represented by 15 trees representing three replicates (5 trees /replicate). The soil of the four orchards was nearly similar as shown in Table (1).

The following topics were studied:

1. Flowering indices: The total number of panicles per tree and number of flowers per panicle were counted (50 panicles from each replicate were randomly chosen and labeled for this purpose).

2. Fruit - set and - retention: Number of set fruits / panicle at initial fruit set and at harvest were recorded and the percent of fruit set and fruit retention was calculated as following equation:

Fruit set $\%=\frac{\text { No. of fruits set /panicle }}{\text { Total No. of flowers / panicle }} \times 100$
Fruit retention $\%=\frac{\text { No. of fruits retained / panicle }}{\text { No. of set fruits / panicle }} \times 100$

3. Yield: It was calculated as weight of fruit $\times$ number of fruits per tree at harvest time

4. Fruit physical and chemical properties: 20 fruits from each replicate were used to determine the physical and chemical properties, concerning weight of both fruit, seed and pulp and fruit dimension were recorded as well as pulp weight percent and fruit shape L/D were also calculated. While fruit chemical properties included, total soluble solids percent $(\%$ T.S.S) was determined by a hand refractometer, total carotenoids was determined according to procedure suggested by Roy (1973), total and reducing sugars were determined as fresh weight according to the method described by Malik and Singh (1980), nonreducing sugars was calculated by the difference between total sugars and reducing sugars.

5. Leaf composition: Leaf samples were collected in July from the middle of vegetative shoots around each of chosen tree, chlorophyll (a) and (b) content were determined as fresh weight according to procedure outlined by Moran and Porath (1980), carbohydrates content was determined on dry weight basis according to the method described by Smith and Dubois (1950). For mineral content determination, nitrogen $(\mathrm{N})$ and phosphorus $(\mathrm{P})$ were determined according to Evenhuis (1976) \& Murphy and Riley (1962), respectively. Potassium (K) was determined by Flame photometer, calcium $(\mathrm{Ca})$, magnesium $(\mathrm{Mg})$, iron $(\mathrm{Fe})$, manganese $(\mathrm{Mn})$, zinc $(\mathrm{Zn})$ and copper $(\mathrm{Cu})$ were determined by Perkin Elmer Atomic Absorption Spectrophotometer.

Results were subjected to analysis of variance were performed according to Snedecor and Cochran (1980) and L.S.D. test (0.05) was used for comparison using SAS ( 1989 ).

\section{RESULTS AND DISCUSSION}

\section{Yield and panicle characteristics:}

The results of both seasons Table (2) revealed that, Zebda mango trees at W.I. (wide intercropping) and M.I. (medium intercropping) systems produced significantly higher number of panicles / tree as compared with those at the control (traditional cultivation T.C.) and C.I (closed intercropping) systems. The differences between W.I. and M.I. as well as between T.C. and C.I. systems did not reach the level of significance in this respect.

The data also showed significant differences between various tested systems concerning number of flowers / panicle. Zebda mango trees at W.I. system ranked first followed in a descending order by those at M.I., T.C. and C.I. systems. This was true in the two seasons of study. These findings relating to number of panicles per tree and number of flowers per panicle may be due to the indirect effect of excessive competition of root system of experimental tree on soil nutrient which depresses vegetative growth. Asada and Ogasawara (1989) concluded that total dry weight gains of Fuji apple trees decreased with increasing shade. The obtained values of both number of panicles/ tree or number of flowers / panicle were in harmony with those mentioned by El-Masry (2001); Tawfik (2003) and Hassan et al (2004) on different mango cvs.

As for number of set fruits/ panicle at initial fruit set, the obtained data indicated that, C.I. system significantly increased number of set fruits/ panicle at initial fruit set followed by T.C. and M.I. systems and the last rank was W.I. system which produced the lowest value in the both seasons.

On regard to fruit set \%, the same table shows a nearly similar trend as observed on number of set fruits / panicle at initial fruit set, i.e. C.I. and T.C. systems were moreeffective in increasing fruit set $\%$ as compared with M.I. or W.I in the both seasons. In other words; number of set fruits / panicle at initial fruit set and fruit set $\%$ significantly increased by decreasing intercropping spacing. Similar results were found by Chalmers et al. (1981) on peach who reported that fruit set $\%$ was increased at the high tree density. In addition, the obtained results are in harmony with those 
mentioned by Dahshan (1971); Shawky et al. (1977) and Nakhlla (1980) on Zebda mango trees.

Concerning number of fruits / panicle at harvest, the obtained results revealed that, "Zebda" mango trees at both of T.C. or W.I. system produced significantly higher number of fruits / panicle at harvest with no significant differences between them as compared with those at M.I. or C.I. system in both seasons. No significant differences were detected in this respect between M.I. and C.I. systems in the two seasons and also between W.I. and M.I. systems in the second season.

Data also show clear differences between four tested systems regarding fruit retention $\%$ at harvest, W.I. system gave significantly higher fruit retention \% followed by T.C. and M.I. systems and the rank last C.I. system. The decrease of number of fruits / panicle and fruit retention $\%$ at harvest in T.C. and all of intercropping systems except W.I. may be due to the light competition which led to photosynthetic yields of mango trees would be higher in the high density planting system than the traditional planting system. These results were confirmed with Chipungahelo et al. (1997) on coconut and pineapple intercrops. In addition, Byers et al. (1985) concluded that shading caused great fruit abscission on peach and apple trees. The present results are also in accordance with those of Desai et al. (1985) and Said and El-Masry (1992) on different mango varieties.

Regarding number of fruits / tree and total yield /tree, the same table shows nearly similar trend as observed on number of fruits / panicle at harvest i.e. Zebda mango trees at T.C. and W.I. systems produced the highest number of fruits /tree and yield / tree as compared with those of M.I. or C.I. in both seasons. Significant differences were, generally, detected in this respect between M.I. and C.I. systems, between W.I. and M.I. systems in the two seasons. These results are in agreement with those reported by Avilan (1986) on mango who recommended that accumulated yields would be higher in the high density planting system than in the traditional planting system, but yields thereafter would be similar in both systems. In addition, Pastor (1984) stated that average annual yield / tree was the highest at the lowest planting density of Manzanillo olive trees. The obtained values of both number of fruits /tree or yield / tree are generally in line with those found by Ahmed et al. (1998); Hoda et al. (2003) and AbdHadi (2006) on different mango cultivars.

\section{Fruit quality:}

Data shown in Table (3) indicated that Zebda mango trees at W.I. produced significantly higher fruit length and diameter than those at other studied intercropping systems and it was similar to those of control (T.C.). This was true in both seasons However, there are no pronounced effect of four studied systems on fruit shape (L/D). The pronounced effect of intercropping spacing on fruit length and diameter may be attributed to the competition between both of vegetative and fruit growth on assimilate demand which were affected by plant spacing (Chalmers et al., 1981). The present results are in line with Smart (1990) who reported that increasing density resulted in an increase in the percentage of pineapple small fruits.

As for weight of fruit and pulp, the same table shows the same trend as observed on fruit length and diameter i.e. weight of fruit and pulp was the heaviest at W.I. and T.C systems with no significant differences between them as compared with M.I. or C.I system in both seasons. The increase in pulp weight was parallel to increase in fruit weight. Data also reveal that there are no significant differences in weight of seeds of Zebda mangoes picked from different studied systems. However significant differences were detected concerning pulp weight $\%$. The percentage of fruit pulp to the total fruit weight was the highest at T.C. and W.I whereas it was the lowest at C.I. system. The obtained values of fruit physical characteristics are generally in harmony with those reported by Abd El- Rahman (1980); Tawfik (2003) and Hassan et al. (2004) on mango.

Regarding fruit chemical composition, data in Table (4) reveal that in both seasons of study, T.S.S.; reducing sugars; and carotenoids content were the highest in Zebda mangoes picked from T.C. (control) followed by those from W.I.; M.I. and C.I. systems. However nonreducing sugars and total sugars contents were the highest at T.C. and W.I. systems with no significant differences between them as compared with those at M.I. or C.I. systems.

Literature concerning the effect of intercropping spacing on fruit quality is not available. but the obtained data of fruit chemical composition are in line with those found by Ibrahim et al. (1985); Mandal et al. (1993); Kunda and Mitra (1997) and Abd El-Hadi (2006) on different mango cultivars. Generally, the effect of intercropping spacing on fruit chemical composition may be attributed to the indirect effect such as low photosynthesis by light competition. These results were

supported by Mika and Piatkowski (1986) who found that mutual shading of density-planted trees, insufficient illumination and tree competition reduced apple fruit quality, whereas the fruits were green and soft with low soluble solids. Likewise, Rom (1990) reported that shade during middle or late of the season tended to reduce apple fruit quality including a decrease 
Table 4. Effect of intercropping spacing on chemical composition of Zebda mango fruits in 2005 and 2006 seasons.

\begin{tabular}{lcccccccccc}
\hline \multirow{2}{*}{ Systems } & \multicolumn{2}{c}{ T.S.S. \% } & \multicolumn{2}{c}{$\begin{array}{c}\text { Reducing } \\
\text { sugars \% }\end{array}$} & \multicolumn{2}{c}{$\begin{array}{c}\text { Non-reducing } \\
\text { sugars \% }\end{array}$} & Total sugars \% & \multicolumn{2}{c}{$\begin{array}{c}\text { Carotenoids } \\
\text { (Mg/100gm) }\end{array}$} \\
\cline { 2 - 11 } & $\mathbf{2 0 0 5}$ & $\mathbf{2 0 0 6}$ & $\mathbf{2 0 0 5}$ & $\mathbf{2 0 0 6}$ & $\mathbf{2 0 0 5}$ & $\mathbf{2 0 0 6}$ & $\mathbf{2 0 0 5}$ & $\mathbf{2 0 0 6}$ & $\mathbf{2 0 0 5}$ & $\mathbf{2 0 0 6}$ \\
\hline T.C. (control) & $15.14 \mathrm{a}$ & $12.71 \mathrm{a}$ & $5.72 \mathrm{a}$ & $4.49 \mathrm{a}$ & $10.41 \mathrm{a}$ & $8.88 \mathrm{a}$ & $16.12 \mathrm{a}$ & $13.37 \mathrm{a}$ & $2.80 \mathrm{a}$ & $2.18 \mathrm{a}$ \\
W.I. & $14.92 \mathrm{~b}$ & $12.54 \mathrm{~b}$ & $5.50 \mathrm{~b}$ & $4.44 \mathrm{~b}$ & $10.40 \mathrm{a}$ & $8.87 \mathrm{a}$ & $15.90 \mathrm{a}$ & $13.31 \mathrm{a}$ & $2.45 \mathrm{~b}$ & $2.11 \mathrm{~b}$ \\
M.I. & $14.54 \mathrm{c}$ & $12.27 \mathrm{c}$ & $3.37 \mathrm{c}$ & $4.29 \mathrm{c}$ & $8.68 \mathrm{~b}$ & $8.58 \mathrm{~b}$ & $12.05 \mathrm{~b}$ & $12.87 \mathrm{~b}$ & $2.39 \mathrm{c}$ & $2.10 \mathrm{~b}$ \\
C.I. & $14.22 \mathrm{~d}$ & $12.01 \mathrm{~d}$ & $3.31 \mathrm{~d}$ & $4.14 \mathrm{~d}$ & $8.52 \mathrm{c}$ & $8.53 \mathrm{~b}$ & $11.83 \mathrm{~b}$ & $12.67 \mathrm{c}$ & $2.37 \mathrm{~d}$ & $1.96 \mathrm{c}$ \\
\hline L.S.D. (0.05) & 0.09 & 0.08 & 0.04 & 0.05 & 0.11 & 0.06 & 0.23 & 0.10 & 0.01 & 0.03 \\
\hline
\end{tabular}

Means within column for season having the same latter are considered insignificant $(\mathrm{p}=0.05)$

T.C. $=$ Traditional cultivation.

W.I. = Wide intercropping.

M.I. = Medium intercropping.

C.I. $=$ Closed intercropping.

Table 5. Effect of intercropping spacing on leaf composition of Zebda mango trees in 2005 and 2006 seasons.

\begin{tabular}{llccccc}
\hline \multirow{2}{*}{ Systems } & \multicolumn{2}{c}{$\begin{array}{c}\text { Chlorophyll (a) } \\
\mathbf{m g} / \mathbf{1 0 0 g m}\end{array}$} & \multicolumn{2}{c}{$\begin{array}{c}\text { Chlorophyll (b) } \\
\mathbf{m g} / \mathbf{1 0 0 g m}\end{array}$} & \multicolumn{2}{c}{ Carbohydrates \% } \\
\cline { 2 - 7 } & $\mathbf{2 0 0 5}$ & $\mathbf{2 0 0 6}$ & $\mathbf{2 0 0 5}$ & $\mathbf{2 0 0 6}$ & $\mathbf{2 0 0 5}$ & $\mathbf{2 0 0 6}$ \\
\hline T.C. (control) & $1.326 \mathrm{a}$ & $1.233 \mathrm{a}$ & $1.153 \mathrm{a}$ & $1.163 \mathrm{a}$ & $13.496 \mathrm{a}$ & $10.950 \mathrm{a}$ \\
W.I. & $1.316 \mathrm{a}$ & $1.181 \mathrm{a}$ & $1.085 \mathrm{a}$ & $1.120 \mathrm{a}$ & $13.186 \mathrm{a}$ & $10.776 \mathrm{a}$ \\
M.I. & $1.016 \mathrm{~b}$ & $0946 \mathrm{~b}$ & $0.770 \mathrm{c}$ & $0.870 \mathrm{~b}$ & $12.466 \mathrm{c}$ & $10.463 \mathrm{c}$ \\
C.I. & $0.810 \mathrm{c}$ & $0743 \mathrm{c}$ & $0683 \mathrm{~d}$ & $0.706 \mathrm{c}$ & $11.946 \mathrm{c}$ & $10.460 \mathrm{c}$ \\
\hline L.S.D. (0.05) & 0.012 & 0.054 & 0.075 & 0.045 & 0.326 & 0.184 \\
\hline
\end{tabular}

Means within column for season having the same latter are considered insignificant $(\mathrm{p}=0.05)$

T.C. $=$ Traditional cultivation.

W.I. = Wide intercropping.

M.I. = Medium intercropping.

C.I. $=$ Closed intercropping

of fruit weight, color and soluble solids.

\section{Leaf composition:}

The results of both seasons Table (5) indicated that M.I. and C.I. systems significantly decreased leaf chlorophyll (a) and (b) and carbohydrates content as compared with W.I.orT.C.

system, the four tested systems could be descendingly arranged as follows:

T.C.; W.I.; M.I. and C.I. systems. The differences between T.C. and W.I. systems did not reach the level of significance in this respect. The decrease in leaf carbohydrates content was concomitant with the decrease in chlorophyll (a) and (b).

Concerning leaf mineral content, data shown in Table (6) indicate that T.C. and W.I. systems significantly increased leaf $\mathrm{N}$ and $\mathrm{P}$ content as compared with M.I. or C.I. system. No significant differences were detected in this respect between M.I. and C.I. systems in the two seasons. Data also show that leaf $\mathrm{K}$ and $\mathrm{Ca}$ content significantly increased with increasing of

intercropping spacing, i.e., W.I. system produced the highest significant leaf $\mathrm{K}$ and $\mathrm{Ca}$ content followed by M.I.; T.C. and C.I. systems in both seasons except in the second season regarding leaf $\mathrm{Ca}$ content, no significant differences were detected between M.I. and C.I. systems.

Regarding leaf $\mathrm{Mg}$ content, the same table shows that all intercropping systems significantly decreased leaf $\mathrm{Mg}$ content as compared with the control (T.C.) which had the highest value in this respect in both seasons except those of C.I. in the second season which did not differ significantly with those of T.C. system.

As for leaf $\mathrm{Fe} ; \mathrm{Zn} ; \mathrm{Mn}$ and $\mathrm{Cu}$ content, data shown in the same table show that all tested systems did not affect $\mathrm{Fe} ; \mathrm{Zn} ; \mathrm{Mn}$ and $\mathrm{Cu}$ content of mango leaves. These results of mineral content are in partial agreement with those found by Schneider et al. (1978) who reported that tree spacing did not affect $\mathrm{N} ; \mathrm{Fe} ; \mathrm{Zn}$ or $\mathrm{Cu}$ content of apple leaves. However, leaves from the widest spaced trees had more $\mathrm{P}$ and $\mathrm{K}$ than those from the closest trees. However, $\mathrm{Ca} ; \mathrm{Mg}$ and $\mathrm{Mn}$ were present 
in greater concentration in leaves from the closely spaced trees. In addition, Rom (1990) also showed that leaves exposed to saturating light have highest $\mathrm{N}$ content.

From obtained results, it can be suggested that, under conditions of this study, wide intercropping (W.I.) system proved to be the suitable system for intercropping

of Zebda mango trees on date palms. This recommended system produced acceptable yield /tree with good quality of mango fruits and was nearly a similar as those of traditional cultivation (T.C.). So the wide intercropping system can be adopted in the main centers of date palms plantation (as Rasheed and Edko, ELBehera Governorate) to generate income without removal date palms.

\section{REFERENCES}

Abd El-Hadi, S.M.K. (2006). Evaluation studies on some mango varieties. Ph.D. Thesis Fac. of Agric., Al-Azhar., Egypt.

Abd El-Rahman, M.A.E.R. (1980). Flavor and color factors in mango fruits during growth and maturation. M.Sc. thesis, Ain Shams University, Cairo, Egypt.

Ahmed, F.F.; A.E.M. Mansour and A.M. Ahmed (1998). A comparative study on fruiting of nine mango cultivars grown under new reclaimed sandy soil. Egypt, J. Hort., 2; 187-193.

Annals of Agricultural Economics, A.R.E (2005). Ministry of Agriculture and Land Reclamation Economic Affairs Sector. Agricultural Statistics. Vol.2 Arabic Rebublic of Egypt.

Asada, T. and M. Ogasawara (1989). The effect of shading on the growth of young "Fuji" apple trees. J. of Japanese Soc. Hort. Sci., 67 (5): 655-659, Fac. of Agric. Hirosaki, Univ. Hirosaki 036, Japan. (Hort. Abst. 69 (1): 90).

Avilan, R.L. (1986). High density planting system in orchards. Sistema de plantacion de alts densidades en frutales. Agronomic Tropical 32 (1/6): 49-67, FONALAP, CENIAP, Apart ado 4653 Maracay 2101 Venezuela. (Hort. Abst. 57 (9): 7397.

Byers, R.E.; C.G. JR. Lyons; K.S. Yoder; J.A. Barden and Young R.W. (1985). Peach and apple thinning by shading and photosynthetic inhibition. J. of Hort. Sci. 60 (4): $465-$ 472. Virginia Polytechnic Institute and State University, Winchester, VA 22601, USA.

Chalmers, D.J.; P.D. Michel and L. Van Heek (1981). Control of peach tree growth and productivity by regulated water supply, tree density and summer pruning. J. Soc. Hort. Sci. 106 (3): 307-312.

Chipungahelo, G.S.; R. Fordham and A. Negreza (1997). Interplanting food crop under coconut palms in red sandy loam of Tanzania. In proceeding international cashew and coconut conference. 17-21 February, Dar Es Salam.
Agronomy section, Agric. Res. Inst., Mickocheni, Ministry of Agriculture PO. Box 6226, Dar Es Salam Tanzania. (Hort. Abst. 69 (3): 2537).

Dahshan, D.I.M. (1971). Studies concerning growth and fruiting in some mango varieties. M.Sc. Thesis, Fac. of Agric.; Ain Shams Univ., Cairo, Egypt.

Desai, A.G.; V.P. Limaye and R.T. Gunjate (1985). Studies on fruit set and fruit drop in Alphonse, Goamankur and Kesar varieties of mango (mangifera indica L.). Maharashtra, journal of Hort., 2 (1): 37-42. ( Hort. Abst. 55: 7334).

El-Masry, S.M. (2001). Selection of some mango seedling in Assiut. Ph. D. Thesis Assiut Univ., Egypt. 195p.

Evenhuis, B. (1976). Nitrogen determination. Dept. Agric. Res. Royal Tropical Inst., Amsterdam.

Hassan, A.M.; Gihan, M.A. and Sanaa, B. (2004). Maturation and heat units (G.D.D.) of some mango cultivars. Egypt. J. Appl. Sci, 19 (5B): 523-571.

Hoda, M.N.; S. Singh and J. Singh (2003). Evaluation of ecological groups of mango (mangifera indica L.) cultivars for flowering under Bihar conditions. India J. Agric. Sci., 73 (2): 101-105.

Ibrahim, A.M.F.; M.M. Attia; A.M. Attalla and A.M. Hussein (1985). Some fruit characteristics of nine mango varieties grown in Behira province, Egypt. J. Agric. Res. Tanta Univ. 11 (2):394-404.

Kunda, S. and S. Mitra (1997). Physiological studies during the growth and development of mango (mangifera indica L.) fruits. Environmental of Ecology, 15 (2): 325-328.

Malik, C.P. and M.B. Singh (1980). Plant enzymology and histoenzymology. A text Manual, Kaylani publishers; New Dulhi.

Mandal, U.; S.K. Mandal and B.C. Mazumdar (1993). Comparative fruit development studies of two new mango varieties in the western lateritic zone of West Bengal. Indian Biologist, 25 (2): 69-71.

Mika, A. and M. Piatkowski (1986). Results of a 10years trial of high-density planting of Macintosh and Macspur apple trees. Acta Horticulturae No. 160, pp. 293-304. Res. Inst. of Pomology and Floriculture, Slierniewice, Poland.

Moran, R. and D. Porath (1980). Chlorophyll determination in intact tissues using N, N-Dimethyl Formamide. Plant physiology. 65: 478-479.

Murphy, J. and J.P. Riley (1962). A modified single solution method for the determination of phosphorus in natural water. Annal. Chem. Acta, 27: 31-36.

Nakhlla, F.G. (1980). Physiological studies on mango. M. Sc. Thesis, Zagazig Univ., Egypt. 117 p.

Pastor, M. (1984). Trail of planting systems with drip irrigation Manzanillo olives. Anales del Instituto Nacional de Investigaciones Agrarias Agricola No. 
27: 21-27, INIA, 14080 Cordoba, Spain. (Hort. Abst. 56 (2): 1437).

Premaratne, W.H.E. and M.P. de Silva (1991). Evaluation of a high intensity mixed cropping model in the mid country of Sri Lanka. Acta Horticulturae, 270: 381-387.

Rom, C.R. (1990). Light distribution and photosynthesis of apple tree canopies. Acta Horticulturae, 279: 283290.

Roy, S.K. (1973). Simple and rapid method for estimation of total carotenoid pigments in mango. J. Food Science and Technology, 10: P. 45.

SAS (1989). Statistical Analysis System. SAS User's Guide Statistics. SAS Institute Inc. Editors, Cary, $\mathrm{NC}$.

Said, G.A. and H.M. El-Masry. (1992). Evaluation of two new introduced mango cvs. Under Giza, conditions. Annal of Agric. Sci. Moshtohor, Egypt. 30 (1): 447-262.

Shawky, I.; Z. Zidan and D.I. Dahshan (1977). Sex distribution, fruit set and fruiting of Zebda mango inflorescence. Annals Agric. Sci., Univ. Ain Shams. 20 (2): 159-166.

Schneider, G.W.; C.E. Chaplin and D.C. Martin (1978). Effect of apple rootstock, tree spacing and cultivar on fruit and tree size, yield and foliar mineral composition. J. Amer. Soc. Hort. Sci. 103 (2):230232.

Smart, G. (1990). Effect of nitrogen manuring and plant density on the fruit size of pineapples. Inligtings Bulletin Navorsings Institut vir Sitrus en Subtropiese Vrugte No. 212: 2-4 (Hort. Abst. 62: 2611).

Smith, F. and M. Dubois (1950). Colormetric method for determined of sugars and related substances Annal. Chem. 28: P. 350.

Snedecor, G.W. and W.G. Cochran (1980). Statistical methods. $7^{\text {th }}$ Ed. Lowa State Univ. Press, Ames Lowa, U.S.A.

Tawfik, E.S.B. (2003). Evaluation of some export mango cultivars grown in Egypt. Ph.D. Thesis, Assiut Univ., Egypt. 


\section{الملخص العربي}

\section{تقييم إنتاجية أشجار المانجو النامية بين أشجار نخيل البلح

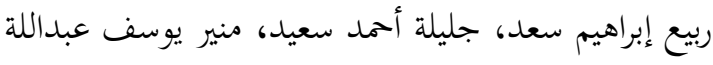 \\ معهد بحوث البساتين مركز البحوث الزراعية ـ الجيزة ـ القاهرة}

العناصر المعدنية كالنتروجين والفوسفور والبوتاسيوم يليها نظام التحميل

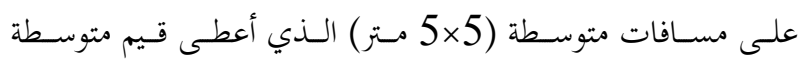

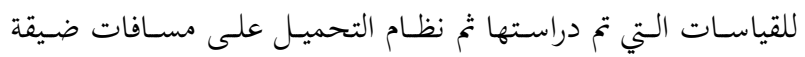
والدي أنتج أقل القيم في معظم القياسات المختبره.

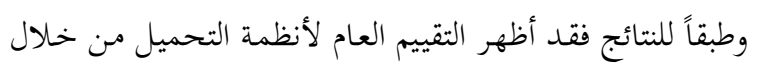

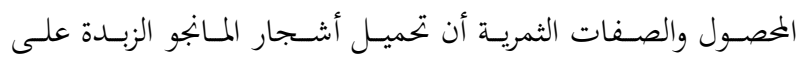

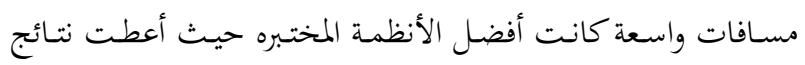

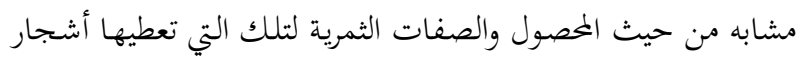

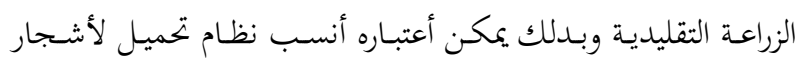

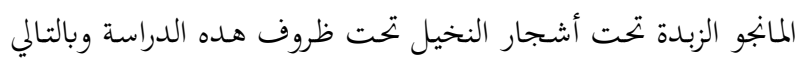

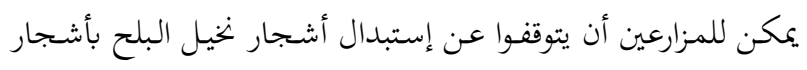

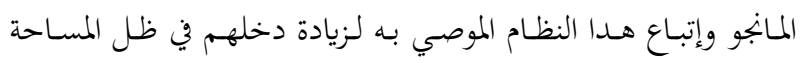

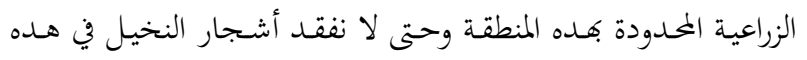
المنطقة التي تعتبر من أشهر مناطق زراعة النخيل في مصر.
أجريت هدة الدراسة لتقييم إنتاجية أشجار المانجو صنف الزبدة

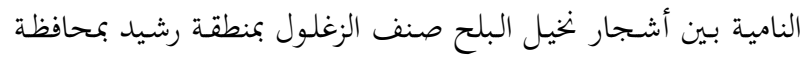
البحيرة وذلك لتحديد أنسب مسافة لتحميل أشجار المانجو على نيخيل

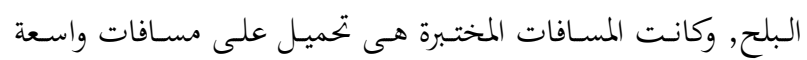

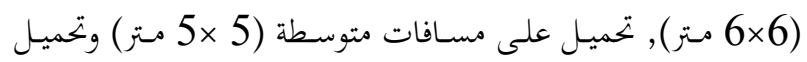

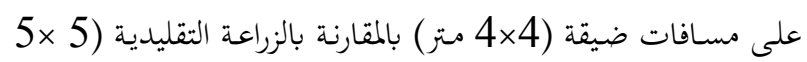
متر بدون تحميل) وقد أوضحت النتائج أن: تحميل أشجار المانجو على مسافات واسعة انتجت أعلى محصول,

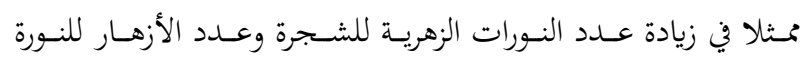

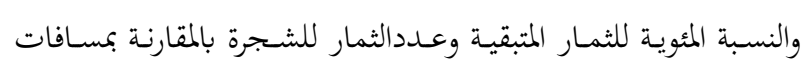

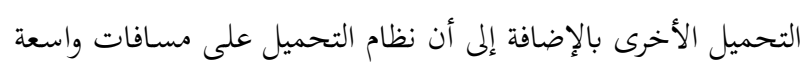

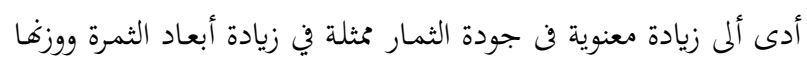

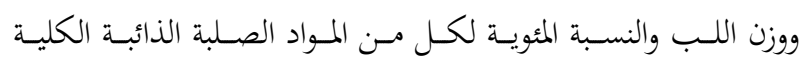

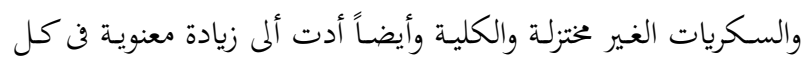

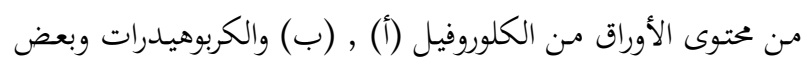

